\title{
Increased insulin action in the rat after protein malnutrition early in life
}

\author{
F. Escriva $^{1}$, M. Kergoat ${ }^{2}$, D. Bailbé ${ }^{2}$, A.M.Pascual-Leone ${ }^{1}$ and B. Portha ${ }^{2}$ \\ ${ }^{1}$ Instituto de Bioquimica-Centro Mixto Universidad Complutense Y CSIC - Facultad de Farmacia, Universidad Complutense, Ciudat \\ Universitaria Madrid, Spain, and ${ }^{2}$ Laboratoire de Physiopathologie de la Nutrition, CNRS URA 307, Université Paris 7, Paris, France
}

\begin{abstract}
Summary. The effect of a limited period of low protein feeding in young rats on insulin secretion and insulin action during adult-age has been studied. Four-week-old rats were maintained for 4 weeks on isocaloric diets containing $5 \%$ protein (low protein) or $15 \%$ protein (control). The low protein rats gained weight at a considerably lower rate than the control rats. This was obtained in the absence of any decrease of spontaneous food intake. Basal plasma insulin levels were decreased $(p<0.01)$ by $40 \%$ in low protein rats. However, the glucose-stimulated insulin secretion obtained in vivo after an i. v. glucose load remained normal. The basal plasma glucose level in the low protein rats was only marginally decreased (by $20 \%$ ). The tolerance to i. v. glucose was found to be slightly enhanced in the low protein rats as compared to the control rats as shown by a significantly increased $\mathrm{K}$ value $(p<0.01)$. In vivo insulin action in the low protein rats was investigated using the euglycaemic-hyperinsulinaemic clamp technique in conjunction with isotopic measurements of glucose turnover.
\end{abstract}

The overall glucose utilization rate was normal in the basal state but significantly increased $(p<0.05)$ when measured at a submaximal plasma insulin level. The basal hepatic glucose production in the low protein rats was similar to that in the control rats. During the clamp studies, the suppression of endogenous glucose production was found to be similar in the low protein rats and the control rats but this was obtained at significantly lower $(p<0.01)$ steady-state insulin levels in the low protein group than in the control group. In conclusion, the current results indicate that the modest improvement of glucose tolerance which is revealed in the low protein rats results from changes in the insulin action upon the target tissues: both the insulin-mediated glucose uptake by peripheral tissues and the ability of insulin to suppress hepatic glucose output are enhanced.

Key words: Insulin action, insulin secretion, low protein diet, malnutrition.
A high prevalence of malnutrition-related diabetic syndromes have been recognized in developing countries [1]. Glucose intolerance is a characteristic feature of proteincalorie malnutrition especially in children suffering from severe protein deficiency [2-5]. The possibility that the impaired glucose tolerance could result from partial failure of the pancreatic Beta-cell function has been raised [5]. However, some confusion still exists in the literature concerning this point as high fasting plasma insulin levels or sustained insulin secretion have been found in some malnourished children [6-8]. Concerning insulin action it has been reported that infants with kwashiorkor were insulin resistant, whereas those with marasmus had normal glucose tolerance despite lower basal and glucose-stimulated insulin levels, thus suggesting enhanced insulin sensitivity [2].

Experimental models of protein-calorie malnutrition might prove helpful because they provide the opportunity for rigorously controlled nutritional experimentation.
Rats have mainly [9-15] been used to characterize the impact of protein-energy deficiency upon the glucose homeostasis. In rats chronically fed with a protein level in the diet comparable to that of humans in developing countries, glucose homeostasis has been evluated through measurements of basal levels of blood glucose or pancreatic hormones [13-15], glucose tolerance tests $[12,14,15]$ or insulin tolerance tests [15]. No direct quantification of insulin action in vivo is presently available in these models. Moreover, one important limitation for the interpretation of results obtained in these animal models of malnutrition, is that they do not allow a separate analysis of the effect of protein deficiency per se from that of energy deficiency since young rats given a low protein-diet spontaneously reduce their food intake [16].

Pilot experiments using Wistar rats given an isocaloric low protein diet ( $5 \%$ ) from weaning, had shown that these rats spontaneously maintained a normal food intake. Taking advantage of this opportunity we have, in the present 
study, characterised the impact of a selective protein deficiency on (1) glucose tolerance, (2) in vivo glucose-induced insulin release, (3) basal and insulin-stimulated in vivo glucose production and glucose utilization, using the euglycaemic-hyperinsulinaemic clamp technique in conjunction with isotopic measurement of glucose turnover.

\section{Materials and methods}

\section{Diet}

The powdered semi-synthetic experimental diets contained $5 \%$ protein (low protein diet, LP) or 15\% protein (control diet, C) and were generously provided by Drs R. Aubert and D.Lemonnier (INSERM-U1, Hôpital Bichat, Paris). The control diet contained by weight (g/100 g): $68 \%$ starch, $4 \%$ cellulose, $5 \%$ lipid (maize oil) and $15 \%$ protein (casein) and by calories $72 \%$ carbohydrate, $12 \%$ lipid and $16 \%$ protein. The LP diet contained ( $\mathrm{g} / 100 \mathrm{~g}): 78 \%$ starch, $4 \%$ cellulose, $5 \%$ lipid (maize oil) and $5 \%$ protein (casein) and by calories $83 \%$ carbohydrate, $12 \%$ lipid and $5 \%$ protein. Both semi-synthetic diets contained $2 \mathrm{~g} / 100 \mathrm{~g}$ yeast and the same salt mixture $(3.5 \mathrm{~g} / 100 \mathrm{~g})$ and vitamin mixture $(2.2 \mathrm{~g} / 100 \mathrm{~g})$. Energy content by $100 \mathrm{~g}$ diet was the same ( 375 calories) in both diets. In $\mathrm{mg} / \mathrm{g}$ of vitamin mixture there were: folic acid 0.094 , biotin 0.047 , vitamin $A$ 469 UI, cholecalciferol 94 UI, menadione 0.469 , thiamin 0.703 , riboflavin 0.703 , pyridoxine 0.469 , calcium pantothenate 2.344 , niacin 2.344, p-aminobenzoic acid 14.062, inositol 23.437, $\alpha$-tocopherol 14.1 UI, choline 93.747, vitamin B-12 0.0023 and cellulose to make $1 \mathrm{~g}$.

In $\mathrm{g} / \mathrm{kg}$ of salt mixture, there were: $\mathrm{CaHPO}_{4} 500, \quad \mathrm{NaCl} 74, \quad \mathrm{~K}_{3} \mathrm{C}_{6} \mathrm{H}_{5} \mathrm{O}_{7} \mathrm{H}_{2} \mathrm{O} 220, \mathrm{~K}_{2} \mathrm{SO}_{4} 52, \quad \mathrm{MgO} 24$, $\mathrm{MnCO}_{3} 3.5, \mathrm{FeC}_{6} \mathrm{H}_{5} \mathrm{O}_{7} \mathrm{H}_{2} \mathrm{O} 0.6, \mathrm{ZnO} 1.6, \mathrm{CuCO}_{3}, \mathrm{Cu}\left(\mathrm{OH}_{2}\right)$ 0.3, $\mathrm{KIO}_{3} 0.01, \mathrm{NaSeO}_{3} 5 \mathrm{H}_{2} \mathrm{O} 0.01, \mathrm{CrK}\left(\mathrm{SO}_{4}\right)_{2} 12 \mathrm{H}_{2} \mathrm{O} 0.55$ and sucrose to make $1 \mathrm{~kg}$.

\section{Animals}

Female Wistar rats bred in our colony were weaned 28 days after birth and then maintained on either the low protein or the control diet. Food intake and body weight were recorded every 2 days.

After feeding the respective diets for 4 weeks, randomly selected animals from each group underwent a glucose tolerance test. The remaining animals in each group were used for measurement of in vivo insulin action with the glucose-insulin clamp technique.

\section{Glucose tolerance tests}

Intravenous glucose tolerance tests $(0.5 \mathrm{~g}$ glucose $/ \mathrm{kg}$ body weight) were performed under pentobarbital anaesthesia $(4 \mathrm{mg} / 100 \mathrm{~g}$ body weight i.p.) at 14.00 hours in rats fasted from 09.00 hours. Blood was withdrawn from the tail vein and samples $(300 \mu 1)$ were immediately centrifuged at $4^{\circ} \mathrm{C}$; plasma was stored at $-20^{\circ} \mathrm{C}$ until assayed.

\section{Euglycaemic-hyperinsulinaemic clamp studies}

Studies were performed at 14.00 hours in rats fasted from 09.00 hours according to a previously detailed procedure $[17,18]$. The rats were considered to be in the post-absorptive period and the rate of glucose production was a measure of endogenous glucose production. Rats were anaesthetized with pentobarbitone. Body temperature was maintained at $37-38^{\circ} \mathrm{C}$ with heating lamps. One carotid artery was catheterized for blood sampling and a tracheotomy was systematically performed to avoid respiratory problems during anaesthesia.
Blood samples of $150 \mu \mathrm{l}$ were collected 20 min after the end of the surgery for the determination of basal blood glucose and plasma insulin concentrations. Then insulin was infused at a constant rate of $20 \mu \mathrm{l} / \mathrm{min}\left(2.1 \mathrm{nmol} \cdot \mathrm{h}^{-1} \cdot \mathrm{kg}^{-1}\right)$ via a saphenous vein and the blood glucose level clamped at the level measured in the basal state by a variable infusion of glucose through the other saphenous vein with a Precidor pump (Infors, Basel, Switzerland). Insulin (porcine monocomponent insulin Actrapid, Novo, Copenhagen, Denmark) was dissolved in $0.9 \% \mathrm{NaCl}$ containing $0.2 \%$ bovine serum albumin (Sigma, St Louis, Mo., USA). The infusion of exogenous glucose ( $4 \%-15 \%$ solution) was started $5 \mathrm{~min}$ after the insulin infusion. Then, $25 \mu 1$ blood was sampled from the carotid artery at 5 min intervals, and plasma glucose concentrations were determined within $60 \mathrm{~s}$ with a glucose analyser (Beckman, Palo Alto, Calif., USA).

Steady-state plasma insulin levels were reached $30 \mathrm{~min}$ after starting the insulin infusion and steady-state blood glucose levels wete reached after 45-50 min. At 55, 60 and $65 \mathrm{~min} 200 \mu \mathrm{l} \mathrm{blood}$ samples were collected to determine blood glucose specific activity and plasma insulin concentrations. The coefficients of variation in plasma glucose and insulin concentrations during the clamp were 5 and $15 \%$, respectively.

\section{Endogenous glucose production}

Endogenous glucose production in the basal state and during the hyperinsulinaemic clamp studies was assessed by a primed continuous infusion of $\left(3-{ }^{3} \mathrm{H}\right)$ glucose (New England Nuclear, Dreiech, FRG). The labelled glucose was adminstered as an initial intravenous priming dose $(4 \mu \mathrm{Ci})$ followed immediately by a continuous intravenous infusion at a rate of $0.2 \mu \mathrm{Ci} / \mathrm{min}$. Steady-state glucose specific activity was established by $40 \mathrm{~min}$ both in the basal state and the clamp studies. The rate of glucose appearance ( $\mathrm{Ra}$ ) was then equal to the rate of glucose disappearance $(\mathrm{Rd})$ and these two parameters were calculated by dividing the $\left(3-{ }^{3} \mathbf{H}\right)$ glucose infusion rate $(\mathrm{dpm} / \mathrm{min})$ by the steady-state value of glucose specific activity $(\mathrm{dpm} / \mathrm{g})$. In the basal state the rate of endogenous glucose production is equal to $\mathrm{Ra}$. In the clamp studies, the rate of endogenous glucose production was calculated by substracting the exogenous steady-state glucose infusion rate (SSGIR) from Ra. The rate of glucose utilized by the whole-body mass (GUR) was calculated as GUR $=\mathrm{Rd}$ and the glucose production rate (GPR) in the liver was calculated as GPR $=\mathrm{Ra}-\mathrm{SSGIR}$.

\section{Samples, analytical techniques and calculations}

Plasma glucose was determined using a glucose analyser (Beckman, Palo Alto, Calif., USA). Blood samples for measuring glucose specific activity were deproteinized with $\mathrm{Ba}(\mathrm{OH})_{2}-\mathrm{ZnSO}_{4}$ and immediately centrifuged. An aliquot of the supernatant was used for the determination of glucose using a glucose oxidase method. Another aliquot of the supernatant was evaporated to dryness at $60^{\circ} \mathrm{C}$ to remove tritiated water. The dry residue was dissolved in $0.2 \mathrm{ml}$ distilled water and counted with $10 \mathrm{ml}$ of Ready-Solv-MP scintillation solution (Beckman). Plasma immunoreactive insulin was estimated using purified rat (studies in the basal state) or porcine (clamp studies) insulin as standards (Novo), antibody to mixed (porcine + bovine) insulin cross-reacting similarly with pork and rat insulin standards and porcine monoiodinated ${ }^{125}$ I-insulin $[17,18]$. Charcoal was used to separate free from bound hormone.

The method allows the determination of $3 \mu \mathrm{U} / \mathrm{ml}(0.12 \mathrm{ng} / \mathrm{ml})$ with a coefficient of variation within and between assays of $10 \%$. The insulin and glucose responses during the glucose tolerance test were calculated as the incremental plasma insulin values integrated over the 30 min period following the glucose injection $\left(\Delta \mathrm{I}, \mathrm{nmol} \cdot \mathrm{min} \cdot \mathrm{l}^{-1}\right)$ and the corresponding incremental integrated plasma glucose values $\left(\Delta \mathrm{G}, \mathrm{mmol} \cdot \mathrm{min} \cdot \mathrm{l}^{-1}\right)$. The rate of glucose disapperance $(\mathrm{K})$ was calculated from the slope of the regression line obtained with the log- 

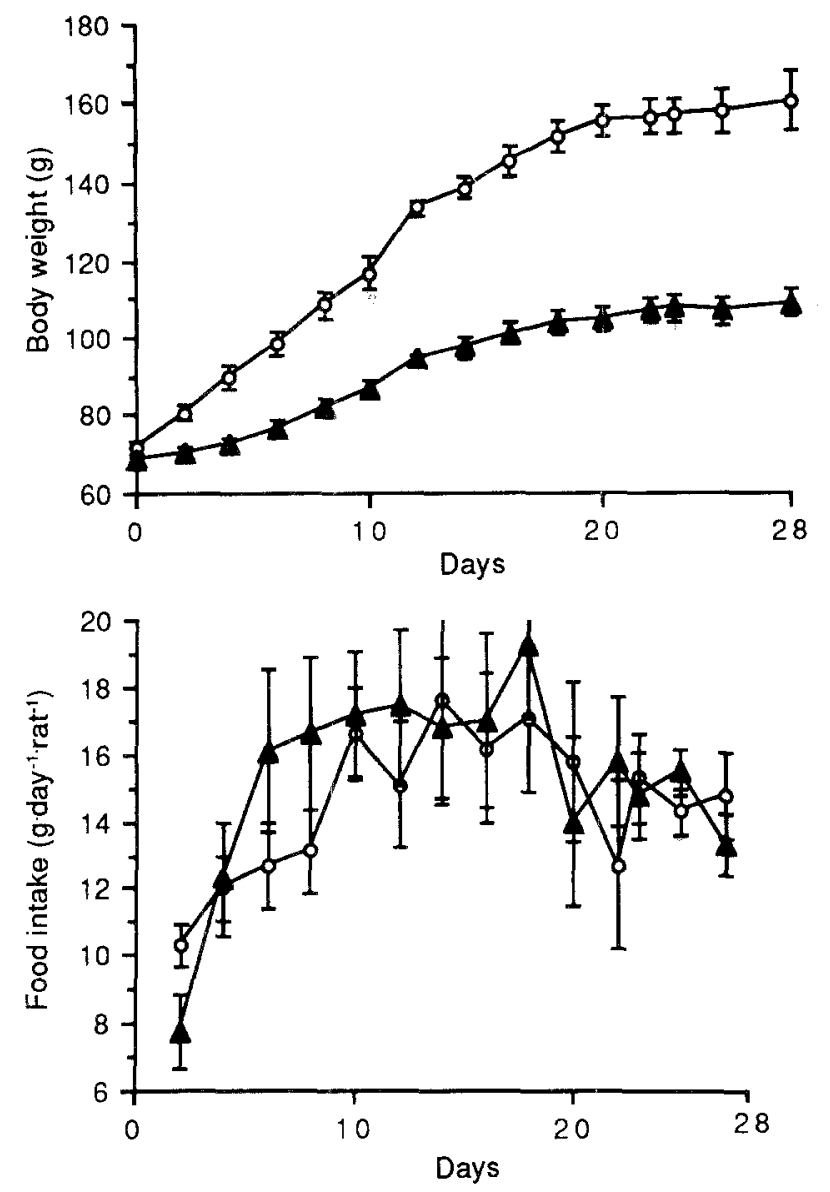

Fig. 1. Evolution of body weight (top) and daily food intake (bottom) of female rats fed a low-protein $\operatorname{diet}(\boldsymbol{\Delta})$ or a control diet ( $O$ ) for 4 weeks. The animals were weaned at 4 weeks of age and placed on either the control diet containing $15 \%$ protein or the low-protein diet containing $5 \%$ protein. The two diets were isocaloric. Values are given as means \pm SEM for $15-21$ rats

transformed plasma glucose values between 5 and $30 \mathrm{~min}$ after glucose administration and was expressed as $\% \min ^{-1}$.

\section{Statistical analysis}

Results are given as means \pm SEM. Statistical analysis were performed using ANOVA.

\section{Results}

\section{Characteristics of the rats}

After weaning ( 4 weeks) rats fed the control diet gained weight and continued to grow throughout the observation period (Fig.1, top). Rats fed the low protein diet gained weight at a considerably lower rate during the same observation period, despite the fact that their daily food intake, and thus their daily energy intake, per animal was not significantly different from that of the control rats (Fig. 1, bottom). Consequently the daily food intake expressed per gramme of body weight was significantly higher in the low protein than in the control rats $(14.5 \pm 0.7 \mathrm{~g} / 100 \mathrm{~g}$ body weight $/ \mathrm{d}, n=13$ and $9 \pm 0.4, n=11$ respectively, $p<0.01)$. Accordingly the food conversion efficiency was decreased in the low protein rats. The protein efficiency ratio (weight gain per gramme of protein eaten) was significantly higher in the low protein than in the control rats $(2.75 \pm 0.27$ vs $1.99 \pm 0.13$, respectively, $p<0.05)$.

When the low protein rats were transferred to the control diet, there was a rapid increase in the rate of weight gain, but no significant change in the daily food intake (data not shown).

The characteristics of the rats killed at the age of 8 weeks are given in Table 1 . In the low protein rats the basal plasma glucose level, measured in the post-absorptive state, was slightly decreased $(p<0.001)$ as compared to that in the control rats. The basal plasma insulin level was more severely decreased $(p<0.001)$ and, hence, the plasma insulin/glucose ratio remained much lower in the low protein rats.

\section{Glucose tolerance and insulin secretory response to glucose}

In response to intravenous glucose load the mean incremental glucose area in the low protein rats was not significantly different from those in control rats while the $\mathrm{K}$ value was significantly increased $(p<0.01)$. Values of the mean incremental insulin area were similar in the low protein and the control rats, thus indicating that the glucoseinduced insulin secretion was not altered in vivo in the low protein rats (Table 1).

Table 1. Characteristics of the animals fed the low protein and control diets

\begin{tabular}{|c|c|c|c|c|c|c|}
\hline \multirow[t]{2}{*}{ Rats } & \multirow{2}{*}{$\begin{array}{l}\text { Body weight } \\
{[\mathrm{g}]}\end{array}$} & \multicolumn{2}{|l|}{ Plasma } & \multirow{2}{*}{$\begin{array}{l}\mathrm{K} \\
{[\% / \mathrm{min}]}\end{array}$} & \multirow{2}{*}{$\begin{array}{l}\Delta \mathrm{G} \\
\mathrm{mmol} \cdot \min \cdot \mathrm{l}^{-1}\end{array}$} & \multirow{2}{*}{$\begin{array}{l}\Delta \mathrm{I} \\
\mathrm{nmol} \cdot \min \cdot \mathrm{I}^{-1}\end{array}$} \\
\hline & & $\begin{array}{l}\text { Glucose } \\
{[\mathrm{mmol} / \mathrm{l}]}\end{array}$ & $\begin{array}{l}\text { Insulin } \\
\text { [nmol/1] }\end{array}$ & & & \\
\hline Control & $\begin{array}{l}167 \pm 4 \\
{[14]}\end{array}$ & $\begin{array}{l}8.0 \pm 0.2 \\
{[12]}\end{array}$ & $\begin{array}{l}0.75 \pm 0.07 \\
{[11]}\end{array}$ & $\begin{array}{l}4.2 \pm 0.3 \\
{[12]}\end{array}$ & $\begin{array}{l}12.6 \pm 1.3 \\
{[12]}\end{array}$ & $\begin{array}{l}4.4 \pm 0.6 \\
{[10]}\end{array}$ \\
\hline Low protein & $\begin{array}{l}118 \pm 5^{b} \\
{[18]}\end{array}$ & $\begin{array}{l}6.2 \pm 0.1^{\mathrm{b}} \\
{[15]}\end{array}$ & $\begin{array}{l}0.44 \pm 0.02^{b} \\
{[11]}\end{array}$ & $\begin{array}{l}5.8 \pm 0.4^{\mathrm{a}} \\
{[15]}\end{array}$ & $\begin{array}{l}12.9 \pm 1.2 \\
{[15]}\end{array}$ & $\begin{array}{l}4.3 \pm 0.2 \\
{[10]}\end{array}$ \\
\hline
\end{tabular}

Mean incremental insulin areas $(\Delta \mathrm{I})$, mean incremental plasma glu- 
Table 2. Levels of glucose and insulin and glucose kinetics during hyperinsulinaemic-euglycaemic clamp in control rats and rats fed a low protein diet for 4 weeks

\begin{tabular}{|c|c|c|c|c|c|c|c|c|c|c|c|}
\hline Rats & $n$ & $\begin{array}{l}\text { IIR } \\
{[\mathrm{mmol} / \mathrm{h} / \mathrm{kg}]}\end{array}$ & $\begin{array}{l}\text { SSPI } \\
{[\mathrm{nmol} / \mathrm{l}]}\end{array}$ & $\begin{array}{l}\mathrm{BBG} \\
{[\mathrm{mmol} / \mathrm{l}]}\end{array}$ & $\begin{array}{l}\text { SSBG } \\
{[\mathrm{mmol} / \mathrm{l}]}\end{array}$ & $\begin{array}{l}\text { SSGIR } \\
{[\mu \mathrm{mol} / \mathrm{min}]}\end{array}$ & $\begin{array}{l}\text { SSGIR } \\
{[\mu \mathrm{mol} / \mathrm{min} / \mathrm{kg}]}\end{array}$ & $\begin{array}{l}\text { GPR } \\
{[\mu \mathrm{mo} 1 / \mathrm{min}]}\end{array}$ & $\begin{array}{l}\text { GPR } \\
{[\mu \mathrm{mol} / \mathrm{min} / \mathrm{kg}]}\end{array}$ & $\begin{array}{l}\text { GUR } \\
{[\mu \mathrm{mol} / \mathrm{min}]}\end{array}$ & $\begin{array}{l}\text { GUR } \\
][\mu \mathrm{mol} / \mathrm{min} / \mathrm{kg}]\end{array}$ \\
\hline C & $\begin{array}{l}7 \\
6\end{array}$ & $\begin{array}{l}0 \\
2.1\end{array}$ & $\begin{array}{l}0.81 \pm 0.05 \\
1.89 \pm 0.21\end{array}$ & $\begin{array}{l}5.9 \pm 0.4 \\
5.6 \pm 0.5\end{array}$ & $\begin{array}{l}6.0 \pm 0.5 \\
5.6 \pm 0.3\end{array}$ & $\overline{12.4 \pm 0.8}$ & $-74 \pm 5$ & & & & $\begin{array}{l}71 \pm 20 \\
96 \pm 17\end{array}$ \\
\hline LP & $\begin{array}{l}8 \\
7\end{array}$ & $\begin{array}{l}0 \\
2.1\end{array}$ & $\begin{array}{l}0.53 \pm 0.05^{\mathrm{b}} \\
1.08 \pm 0.09^{\mathrm{b}}\end{array}$ & $\begin{array}{l}5.3 \pm 0.3 \\
5.2 \pm 0.3\end{array}$ & $\begin{array}{l}5.2 \pm 0.2 \\
5.9 \pm 0.2\end{array}$ & $\overline{15.8 \pm 0.8^{\mathrm{a}}}$ & $-\overline{135 \pm 7^{\mathrm{b}}}$ & $\begin{array}{l}9.7 \pm 1.0 \\
4.5 \pm 0.9\end{array}$ & $\begin{array}{l}76 \pm 15 \\
28 \pm 7\end{array}$ & $\begin{array}{c}9.7 \pm 1.0 \\
20.2 \pm 0.9^{\mathrm{a}}\end{array}$ & $\begin{array}{c}76 \pm 15 \\
177 \pm 12^{b}\end{array}$ \\
\hline
\end{tabular}

Values are mean \pm SEM. C: control diet; LP: low protein diet; IIR: insulin infusion rate; SSPI: steady-state plasma insulin; BBG: basal blood glucose; SSBG: steady-state blood glucose; SSGIR: steady state glucose; GPR: glucose production rate; GUR: glucose utilization rate.

${ }^{\mathrm{a}}=p<0.02 ;{ }^{\mathrm{b}}=p<0.01$ vs related control group

\section{In vivo insulin action}

The basal rate of glucose production in the low protein rats was similar to that in the control rats (Table 2). Following a submaximal hyperinsulinaemia (1.08 \pm $0.09 \mathrm{nmol} / 1$ in the low protein group; $1.89 \pm 0.21 \mathrm{nmol} / 1 \mathrm{in}$ the control group) endogenous glucose production was similarly suppressed in both groups. However, this was obtained under significantly lower steady-state plasma insulin levels $(p<0.01)$ in the low protein than in the control group. The same conclusion was reached when the values were expressed per rat or per $\mathrm{kg}$ body weight.

The basal rate of glucose utilization was similar in the low protein and in the control rats (Table 2). Following submaximal hyperinsulinaemia glucose utilization in the low protein rats was significantly increased as compared to that in the control rats: this was observed whenever the results were expressed per animal $(p<0.02)$ or per $\mathrm{kg}$ body weight $(p<0.001)$.

\section{Discussion}

This study confirms previous observations [13-15, 19-23] that a diet low in protein $(<6 \%)$ does not support normal growth in young rats. Such a model of malnutrition was obtained in the present work in the absence of a decreased spontaneous food intake. This is remarkable as several previous reports using a similar diet protocol to ours concluded that rats fed such low protein diets reduce their food intake to a level just sufficient to maintain body weight $[13-15,24]$. However, our observation is not unique since the increased food intake (when corrected for the body weight) and the increased protein efficiency ratios found in the present work, have been reported previously [25-27]. In these reports, including ours, the common result of the low protein diet was a moderate growth retardation in rats. This is at variance with the more drastic growth arrest observed in previous studies [13-15]. The increase we found in the protein efficiency ratio in the low protein rats could reflect a proportionately greater utilization of the protein for growth in these rats and represent an adaptative change to limit growth retardation. The increased food intake relative to body weight may represent a mechanism by which low protein rats partially compensate their low protein intake. In addition, the excess nonprotein energy intake by these rats (when expressed per gramme body weight) may have been stored as glycogen, fat and/or wasted [26, 27]. Furthermore, it has been reported that in young growing animals the consequences of consuming low protein diets may vary as regards carcass fat accumulation [28-30]. The results obtained depend on the age of the animals, whether the low level of protein is near or below the requirement, as well as other dietary components. Taken together the animal model presently used produces selective protein deficiency with no associated calorie malnutrition. Such a model makes it possible to dissociate the effects of protein deficiency per se from those of energy deficiency, as these two parameters are intimately associated in the syndrome of kwashiorkor in childhood [5] and in animal models of malnutrition recently studied [13-15].

Basal plasma insulin levels were lower in the proteindepleted rats. Other investigators have also reported that insulin levels were reduced in malnourished rats [13-15, $24]$. In contrast to the very poor in vivo and in vitro insulin responses to glucose reported in protein-calorie malnutrition models [1, 13-15, 31], we found a normal glucosestimulated insulin secretion in vivo. Our observation suggests that the low responsiveness of the Beta-cells to glucose as shown during protein-calorie malnutrition, can be attributed mainly to the calorie deficiency.

Under basal conditions, low protein fed rats succeeded in maintaining low or near normal plasma glucose levels with low plasma insulin levels. This is in accordance with the results found in a similar low protein fed rat model [27]. It was also reported that the basal plasma glucagon level remained normal and that the plasma free triiodothyronine level increased [27]. Tolerance to intravenous glucose was slightly better in low protein fed rats than in control rats, as shown by a significantly increased glucose disappearance rate ( $\mathrm{K}$ value). This suggests an increased sensitivity to insulin in the rats fed the low protein diet.

However, the relationship between the $\mathrm{K}$ value and the effects of insulin on glucose-uptake is not a direct one; therefore we have investigated insulin action in rats fed a low protein diet using the insulin-glucose clamp technique in conjunction with isotopic measurements of glucose turnover. During the clamp experiments performed at similar blood glucose levels in both groups, the rate of exogenous glucose infusion required to maintain the blood glucose level at euglycaemia and at steady-state plasma insulin, is taken as a measure of the effect of insulin on total-body glucose metabolism. Under the present experimental conditions the glucose infusion rate is equal to the sum of the decrement in glucose production and the 
increment of glucose utilization caused by insulin. The total-body glucose metabolism in low protein fed rats was significantly higher from that in the control rats at submaximal insulin levels which indicates that the total-body glucose metabolism is most responsive to insulin in the low protein as compared to the control rats.

The basal glucose utilization rate was significantly higher in low protein fed rats. During the clamp studies the glucose utilization induced by submaximal insulin levels (when related to body mass) was significantly greater in the low protein fed rats than in the control rats. These data suggest that insulin-mediated glucose uptake is enhanced in the low protein fed rats. Our conclusions are similar to those reported in protein-calorie deficient rats. In these models as compared to normal rats, it has been shown that despite reduced basal plasma insulin levels, the clearance of glucose from the blood was kept to normal [24], that exogenous insulin caused a more sustained hypoglycaemia [15] and that soleus muscle preparations in vitro were more sensitive to insulin [32].

One of the aims of our study was to evaluate the effect of insulin on endogenous glucose production in low protein fed rats. As the rats were in the postabsorptive state, it can be assumed that the rate of glucose production represents hepatic glucose production. In the basal state, hepatic glucose production in the low protein fed rats was similar to that in the control rats. This was true even though the plasma insulin levels were lower, suggesting an increased hepatic sensitivity to insulin in the low protein fed rats. This conclusion is based on the fact that during the euglycaemic clamp studies, the suppression of glucose production induced by submaximal insulin levels was similar in the low protein fed and in the control rats despite significantly lower $(p<0.01)$ steady-state plasma insulin levels in the low protein rats. Such a conclusion is in line with the recent report that the suppression of endogenous glucose production during glucose infusion in protein-depleted rats was similar to that in control rats, despite insulin levels in the protein-depleted group that were $1 / 3$ of those of the control group [24]. We are not aware of any detailed study of the in vivo insulin action on the liver of protein-depleted rats. Nevertheless it has been observed that young rats fed a low protein diet exhibited low hepatic glucose-6-phosphatase and alanine-aminotransferase activity [24]. This could explain how malnourished rats succeed in maintaining normal endogenous glucose production with low plasma insulin levels. It has also been recently reported [27] that both phosphoenolpyruvate carboxykinase and pyruvate kinase activities are high in the liver of low protein fed young rats. The development of a futile cycle between pyruvate and phosphoenolpyruvate may contribute to the wastage of the excess non-protein energy intake and be partly responsible for the observed decreased food conversion efficiency in the low protein fed rats [27].

In conclusion the results indicate that a selective protein depleted feeding in the young rat in the absence of caloric deprivation decreases the basal plasma insulin level but does not lead to any impairment of glucose-induced insulin secretion. Furthermore, they provide direct evidence that the modest improvement of glucose tolerance results from changes in the effect of insulin upon the target tissues. Both the insulin-mediated glucose uptake by peripheral tissues and the ability of insulin to suppress hepatic glucose output are enhanced.

Acknowledgements. We are grateful to Drs E.Forgue-Laffitte and G. Rosselin (INSERM- Unité55-Paris) for the gift of iodinated insulin, and to Drs R. Aubert and D. Lemonnier (INSERM-Unité1Paris) for the semi-synthetic diets. This work was partly susported by the France/Spain programme for Science (Actions Intégrées 149 and 216).

\section{References}

1. WHO Study Group (1985) Diabetes Mellitus. Geneva, World Health Org., (Tech Rep Ser 727) pp 20-25

2. Bowie MD (1964) Intravenous glucose tolerance in kwashiorkor and marasmus. S Afr Med J 38: 328-329

3. Milner RDG (1971) Metabolic and hormonal responses to glucose and glucagon in patients with infantile malnutrition. Pediatr Res 5: 33-39

4. Becker DJ (1983) The endocrine responses to protein calorie malnutrition. Annu Rev Nutr 3: 187-212

5. Rao RH (1988) Diabetes in the undernourished: coincidence or consequence. Endocrine Rev 9:67-87

6. Baig HA, Edozien JC (1965) Carbohydrate metabolism in kwashiorkor. Lancet II: 662-665

7. Hadden DR (1967) Glucose, free fatty acid and insulin interrelations in kwashiorkor and marasmus. Lancet II: 589-593

8. Becker DJ, Pimstone BL, Hansen JDL, MacHutchon ZB, Drysdale A (1972) Patterns of insulin response to glucose in proteincalorie malnutrition. Am J Clin Nutr 25: 490-505

9. Bhutani V, Kumar V, Misra UK (1975) Effect of inadequate dietary proteins on pancreatic insulin and cAMP levels in rats. Nutr Rep Int 32: 1413-1420

10. Weinkove C, Weinkove EA, Pimstone BL (1976) Glucose tolerance and insulin release in malnourished rats. Clin Sci Mol Med 50: $153-163$

11. Younoszai R, Dixit PK (1980) Decreased insulin secretion by isolated pancreatic islets from rats fed $4 \%$ protein diet. Proc Soc Exp Biol Med 164: 317-321

12. Levine LS, Wright PG, Marcus F (1983) Failure to secrete immunoreactive insulin by rats fed a low protein diet. Acta Endoctinol 102: 240-245

13. Dollet JM, Beck B, Villaume C, Max JP, Debry G (1985) Progressive adaptation of the endocrine pancreas during long term protein deficiency in rats: effects on blood glucose homeostasis and on pancreatic insulin, glucagon and somatostatin concentrations. J Nutr 115: 1581-1588

14. Swenne I, Crace CJ, Milner RDG (1987) Persistent impairment of insulin secretory response to glucose in adult rats after limited period of protein-calorie malnutrition early in life. Diabetes 36 : $454-458$

15. Okitolonda W, Brichard SM, Henquin JC (1987) Repercussions of chronic protein-calorie malnutrition on glucose homeostasis in the rat. Diabetologia 30: 946-951

16. Phillips LS (1981) Nutrition, metabolism and growth. In: Daughaday WH (ed) Endocrine control of growth. Elsevier, New York, pp 121-173

17. Kergoat M, Portha B (1985) In vivo hepatic and peripheral insulin sensitivity in rats with non-insulin-dependent diabetes induced with streptozotocin. Assessment with the insulin-glucose clamp technique. Diabetes 34: 574-579

18. Blondel O, Bailbe D, Portha B (1989) Relation of insulin deficiency to impaired insulin action in NIDDM adult rats given streptozotocin as neonates. Diabetes 38: 610-617

19. Widdowson EM, McCance RA (1957) Effect of a low-protein diet on the chemical composition of the bodies and tissues of young rats. Br J Nutr 11: 198-206 
20. Hill DE, Hold AB, Parra A, Cheek DB (1970) The influence of protein-calorie versus calorie restriction on the body composition and cellular growth of muscle and liver in weanling rats. Johns Hopkins Med J 127: 146-63

21. Stead RH, Brock JP (1972) Experimental protein-calorie malnutrition. Rapid induction of protein depletion signs in earlyweaned rats. J Nutr 102: 1357-1366

22. Weinkove C, Weinkove E, Imme A, Pimstone B (1977) Pancreatic islets in malnourished rats. Quantitative histologic and electron microscopic findings. Arch Pathol Lab Med 101:266-269

23. Timson BF, Dudenhoeffer GA (1985) The effect of severe dietary protein restriction on skeletal muscle fiber number area and composition in weanling rats. J Anim Sci 61: 416-422

24. Crowe PJ, Royle GT (1988) Glucose kinetics in protein depletion. Effects of glucose infusion in the fasted rat. J Nutr 118: $1240-1244$

25. Hegsted DM, Neff R (1970) Efficiency of protein utilization in young rats at various levels of intake. J Nutr 100: 1173-1179

26. Rothwell NJ, Stock MJ, Tizbir RS (1983) Mechanism of thermogenesis induced by low protein diets. Metabolism 32: 257-261

27. Claeyssens S, Lavoine A, Fresel-Ragot M, Bois-Joyeux B, Chanez M, Perret J (1990) Metabolic changes in rats fed a low protein diet during post weaning growth. Metabolism 39: 676-681

28. Meyers JH (1958) Interactions of dietary fiber and protein on food intake and body composition of growing rats. Am J Physiol 193: 488-494
29. Meyers JH, Hargus WA (1959) Factors influencing food intake of rats fed low protein rations. Am J Physiol 197: 1350-1352

30. Swick RN, Grisbskov CL (1983) The effect of dietary protein levels on diet induced thermogenesis in the rat. J Nutr 113: 2289-2294

31. Swenne I, Crace CJ, Jansson L (1988) Intermittent protein-calorie malnutrition in the young rat causes long-term impairment of the insulin secretory response to glucose in vitro. J Endocrinol 118: 295-302

32. Crace CJ, Swenne I, Kohn PG, Strain AJ, Milner RDG (1990) Protein-energy malnutrition induces changes in insulin sensitivity. Diabète Métab 16: 484-491

33. Heard CRC, Frangi SM, Wright PM, McCartney PR (1977) Biochemical characteristics of different forms of protein energy malnutrition: an experimental model using rats. Br J Nutr 37: 1-21

Received: 27December 1990

and in revised form: 26 April 1991

Prof. B.Portha

Laboratoire de Physiopathologie de la Nutrition

CNRS URA 307

Université de Paris 7

2 Place Jussieu, Tour 33

F-75251 Paris Cedex 05

France 